\title{
The Implementation of Contractor Safety Management System to Prevent Work Accidents at Coal Mining Company
}

\section{Penerapan Contractor Safety Management System untuk Mencegah Kecelakaan Kerja di Perusahaan Tambang Batu Bara}

\author{
Nadia Nur Amalina ${ }^{1}$, Hanum Elok Larasati ${ }^{2}$ \\ ${ }^{1}$ Department of Occupational Safety and Health, Faculty of Public Health, Universitas Airlangga \\ Campus C Mulyorejo, Surabaya, East Java, 60115 Indonesia \\ ${ }^{2}$ UPN "VETERAN" Yogyakarta \\ Jl. SWK 104 (Lingkar Utara), Condongcatur, Yogyakarta 55283 Indonesia
}

\begin{abstract}
Introduction: The coal mining company is a company that plays an important role in the Indonesia' economy, but it is one of the high potential risk industry because most of its activities are carried out by contractors who generally undisciplined and have a lack understanding of Occupational Safety and Health. To solve this problem, the Contractor Safety Management System (CSMS) program must be conducted. The purpose of this study was to determine the implementation of CSMS program in a coal mining company in Indonesia. Methods:This cross-sectional study was conducted at a coal mining company in South Kalimantan in 2017 and analyzed descriptively. The CSMS stages and its program were obtained by direct observation using checklist sheets and study documents. Results: The CSMS procedure at the coal mining company started with risk assessment, pre-qualification, qualification, pre-work, monitoring and evaluation activities. To increase the effectiveness of the OSH program, the coal mining company also conducted additional activities such as supervisor competency training, general morning talk, technology guidance, audits and occupational safety health as well as environment seminars. Work accidents rate at three main contractors in the coal mining company was effectively reduced after an audit and improvement of the implementation of CSMS in 2016. Conclusion: CSMS activities in coal mining company have been carried out routinely and systematically where monitoring activities are carried out by coal mining company's and sub/contractors's QHSE officer, and the implementation of CSMS that is consistent and fit to the standards in 2016 proven to reduce the work accident rates in the coal mining company.
\end{abstract}

Keywords: coal mining, contractor safety management system, work accident prevention

\section{ABSTRAK}

Pendahuluan:Perusahaan tambang batu bara merupakan perusahaan yang berperan penting terhadap perekonomian negara, namun termasuk dalam industri yang padat risiko karena sebagian besar aktivitasnya dilakukan oleh kontraktor yang umumnya kurang disiplin dan memiliki pemahaman rendah mengenai K3. Untuk menanggulangi masalah tersebut dilakukan program Contractor Safety Management System (CSMS). Tujuan penelitian ini adalah untuk mengetahui penerapan program CSMS di salah satu perusahaan tambang batu bara di Indonesia. Metode: Penelitian cross-sectional ini dilakukan di perusahaan tambang batu bara di Kalimantan Selatan pada tahun 2017 dan dianalisa secara deskriptif. Tahapan dan program CSMS diperoleh dengan cara observasi langsung menggunakan lembar checklist dan studi dokumen Hasil: Prosedur CSMS yang dilakukan di perusahaan batu bara dimulai dari kegiatan risk assessment, pra kualifikasi, kualifikasi, pra pekerjaan, monitoring, dan evaluasi. Untuk meningkatkan efektivitas program $k 3$ dan meminimalkan risiko kecelakaan kerja maka perusahaan tambang batu bara juga melakukan kegiatan tambahan seperti kompetensi penanggung jawab operasional, general morning talk, bimbingan teknologi, audit dan seminar K3LH. Angka kecelakaan kerja pada tiga kontraktor utama di perusahaan tambang batubara secara efektif berkurang setelah dilakukan audit dan perbaikan pelaksanaan CSMS pada tahun 2016. Simpulan: Kegiatan CSMS di perusahaan tambang batu bara telah dilakukan secara rutin dan tersistematis dimana kegiatan monitoring dilakukan oleh kedua belah pihak, yaitu QHSE perusahaan tambang batu bara dan QHSE sub/kontraktor, serta penerapan CSMS yang konsisten dan sesuai dengan standard di tahun 2016 terbukti mampu menurunkan angka kecelakaan kerja di perusahaan tambang batu bara.

Kata kunci: pencegahan kecelakaan kerja, sistem manajemen keselamatan kontraktor, tambang batu bara 


\section{Corresponding Author:}

Nadia Nur Amalina

Email : nadia.nur.amalina-2018@fkm.unair.ac.id

Telephone : +6281806411186

\section{INTRODUCTION}

The development of industry throughout the world has made an aspects of occupational health and safety as matter that must be considered and implemented by workers, employers, and government. This is because each work activities has its own potential hazards, so the workers are at risk of accidents due to their work.

Occupational accident is an undesirable event caused by a hazard that exists in the workplace and unsafe behaviour that causes harm to workers as well as employers in material and non-material aspect (Bird, Germain and Clark, 2003).

Annual estimation obtained of more than 250 million cases of accidents occur at work and more than 160 million workers are sick because of hazards at work. Moreover, 1.2 million workers died as a result of accidents and illness at work (International Labour Organizational, 2013).

According to Ministry of Manpower website, in Indonesia, work accident cases are still very high annually. Based on data from the Social Security Administration, work accident cases reported in 2017 was around 123,041 cases, and increased in 2018 to 157,313 cases. In September 2019, the number of work accident was 130,923 cases. Eventhough the number of work accident in 2019 decreased, but this is still high and it cannot be underestimated.

The mining industry is an industry that plays an important role in the country's economy so there's a lot of mining industry commodities in Indonesia. In 2013, Indonesia was listed as the third largest coal producer and exporter in the worldwide.

The coal mining industry has a number of characteristics, which are high capital, high technology, and high risk. This is happened because of there is an interaction between humans, machines, equipment and environmental factors that result in potential hazards that can lead to occupational health and accident risks. This is in line with other study that according to Ministry of Energy and Mineral Resources in 2017, there was 146 mining workers were fatally injured in accidents at mining sites in the last five years (Anggoro and Simorangkir, 2019).

Accident and ill-health record of mining sectors are more poorly than the other sectors such as manufacturer and construction. Based on that fact, mining sectors known as the most dangerous industry (Hermanus, 2007).

Contractor is an important element as a partner who helps the company's operations. The contractor itself is very accident-prone in carrying out its activities. This is because the workers who work are temporary, have low education, are not discipline in working, havelow understanding of company OSH regulations, and are directly involved in the implementation of work so that they are more exposed to hazard. In addition, some of contractor's knowledge about the company's OSH regulations is poor (Abdul-Rashid, Bassioni and Bawazeer, 2007).

The fourth largest coal mining company in the world is located in South Kalimantan, Indonesia and it also gets a title of the largest coal mining company in South Kalimantan. The area of that company is $35,800.80 \mathrm{Ha}$ with 22,037 workers consisting of 1,027 permanent workers, 13 foreign workers and 20,997 workers from contractor and subcontractor.

Most of the work activities at the coal mining company is carried out by contractor, so that contractor workers have a greater risk of exposure to hazards. To prevent accidents due to work, strict control and supervision are needed to ensure that contractors are concern about Occupational Safety and Health, one of which is by implementing a Contractor Safety Management System (CSMS).

CSMS is a comprehensive system and management of the contractors starting from the planning stage to the implementation of work (Ramli, 2008). According to OGP, CSMS is a document that contains a control mechanism in the form of guidelines to guarantee business standards in managing the performance of Occupational Safety, Health and Environmental Protection of the contractors (Haryanti, 2016).

CSMS is used by users or companies in assessing the performance of contractors who will be partners in the implementation of their work. This can be one of the prevention efforts in controlling work accidents that occur to contractors (Pratiwi, 2017).

The largest coal mining company in South Kalimantan have implemented CSMS since 1990 which is integrated with the Mining Safety Management System (MSMS) based on the Regulation of the Minister of Energy and Resources No. 38 of 2014 (Minister of Energy and Mineral Resources, 2014). From the beginning of its 
implementation until 2009, the number of sub/ contractors at the largest coal mining company in South Kalimantan was invalid and uncontrolled so that a database was made up to the CSMS audit for the first time in 2012.

In 2014, the largest coal mining company in South Kalimantan started to collect and optimize the empowerment sub/contractor, from $250 \mathrm{sub} /$ contractor to $151 \mathrm{sub} /$ contractor in 2017. CSMS program became more developed and effective in 2017, because the evaluation of CSMS started on that year. This study aimed to determine the implementation of CSMS program in the largest coal mining company in South Kalimantan.

\section{METHODS}

This research was conducted using observational method because the data were obtained through document studies and direct observation under guidance of Quality, Health, Safety and Environment (QHSE) officer using a checklist sheet of the research object that adapted from Prequalification CSMS sheets and procedure used to know the stages of CSMS implementation in the largest coal mining company in South Kalimantan. The objects did not get any intervention or treatment during this research.

There were three variables in this study, including CSMS's stages and programs and the number of work accidents in sub/contractors after the implementation of CSMS. The data were analyzed descriptively to know whether the implementation went according to organizational work procedure of the largest coal mining company in South Kalimantan. When it viewed in terms of time, this research was cross-sectional because it was done in a certain time. The study was conducted at the Largest Coal Mining Company in South Kalimantan on February $1^{\text {st }}$ - March 31 2017.

\section{RESULT}

\section{Implementation of CSMS}

The largest coal mining company has been carrying out CSMS program since 1990, but the system has been developed and improved until 2017. The stages of the implementation of CSMS carried out in the largest coal mining company in South Kalimantan are presented as Figure 1.

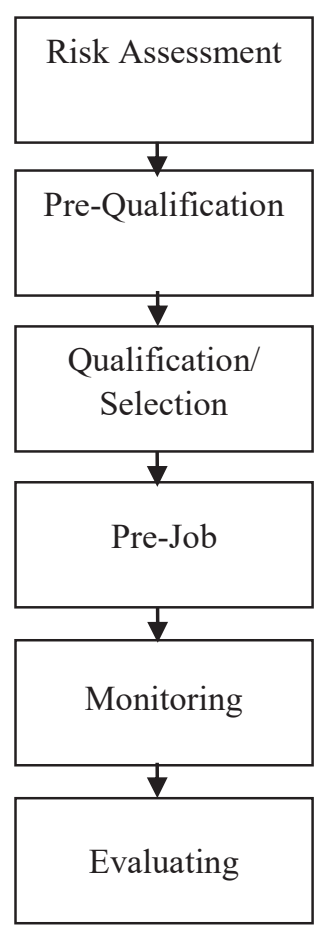

Figure 1. The stages of CSMS in the Largest Coal Mining Company in South Kalimantan

\section{Risk Assessment Stage}

The first step was to conduct an initial risk assessment based on the description of the work that has been made previously. Risk assessment can be categorized into low, medium, and high according to the risk assessment matrix. This activity was carried out by the largest coal mining company in South Kalimantan towards the sub/ contractor before the CSMS submission was carried out so the coal mining company and sub/contractor could determine the steps of Occupational Safety Health and Environment (OSHE) management in accordance with the level of work risk.

The results obtained from the risk assessment stage were the level of risk in each type of work that would be done by the sub/contractors, ranging from low risk jobs such as suppliers of non-mining equipment (fire extinguishers), to high risk jobs, such as drilling, logging, and draught survey.

\section{Pre-Qualification Stage}

This stage was carried out by the user with the aim of screening the sub-contractors. The user provided a pre-qualification questionnaire that contained a list of questions and special requirements to be subsequently fulfilled by prospective sub/ contractors. 


\section{Qualification/Selection Stage}

At this stage, the sub/contractor went through five steps to meet the standard requirements proposed by the largest coal mining company in South Kalimantan, they were CSMS submission, fulfillment of requirements, data verification, registration and input data, and CSMS eligibility test.

Prospective sub/contractors must prepare a CSMS registration request letter and fulfill CSMS requirements to ensure that they have the ability and experience to carry out work safely, care for the environment and have awareness of their social impact on the local community.

The CSMS requirements document was assessed by the HSE team of the largest coal mining company in South Kalimantan. If there are prospective sub/ contractors who do not reach the minimum value, the coal mining company will provide an opportunity for prospective sub/contractors to meet the existing gap, but within a period of time and strict supervision.

The results of the data verification process were then recorded electronically in the database and the contractor who passed the fan verification met the requirements and would get a CSMS eligibility certificate.

\section{Pre-Job Stage}

This stage aims to ensure that all aspects of Occupational Safety Health and Environment (OSHE) that are relevant to the results of the risk assessment can be communicated and understood by all parties prior to the implementation of the contract so that there are no misunderstandings that can lead to work accidents in the future.

OSHE aspects of communication activities were carried out through kick-off meetings, induction and commissioning. Kick-off Meeting is done before the work starts. Things discussed in the kick-off meeting are work plans, accident reporting systems, work reporting systems and technical aspects led by representatives of coal mining company and attended by contractors and supervising contractors as the part of the largest coal mining company in South Kalimantan.

Induction was carried out to the new employees, visitors, and employees who have just finished their annual leave. After one year, the company will held a re-induction activity to refresh their memory. The purpose of the induction activity is to make the sub/contractor employees recognize the work environment area, facilities, emergency evacuation sites, and safety procedures while working at the largest coal mining company in South Kalimantan. The output of this induction activity is mining permit.

The commissioning activity aims to ensure that the infrastructure and equipment that will enter the operational area of the largest coal mining company in South Kalimantan are in accordance with the standards so that they will not cause work accidents that result in material and immaterial losses. This activity is carried out every three months by technical workers and controlled by HSE officer to ensure the safety.

\section{Monitoring}

Monitoring activities were carried out by the largest coal mining company in South Kalimantan through two systems, those were the class system and the door to door system.

Monitoring activities carried out consisted of inspection and self-assessment by the sub/contractor itself. The inspection was carried out in workshop areas, canteen, office, mess, clinic, and opperational areas by the largest coal mining company in South Kalimantan and sub/contractor's QHSE.

\section{Evaluation}

The frequency of evaluations depended on the type of work, the size of the work, and the risk of work in the largest coal mining company in South Kalimantan database, where previously a simple checklist of low risk contracts was conducted or a more analytical approach to high risk contracts.

If there were sub/contractors who have committed minor violations, there would be an opportunity for repairs and repetition of audits, but if it was known that there were sub/contractors who have committed serious violations, then the contract was terminated by the largest coal mining company in South Kalimantan. The criteria of minor violation of sub/contractors did not implement the system properly and non-fatality incident has happened at least once a year. Otherwise, the criteria of major or serious violation were in the form of no effective further action when the violation happened, fatality incidents have ever happened, and environment incident has ever happened causing complaint and penalty to the largest coal mining company in South Kalimantan. 


\section{The Improvement of OSHE Contractor Program}

\section{Supervisor Competency Training}

The largest coal mining company in South Kalimantan facilitates their contractors and subcontractors in carrying out OSHE supervisor competency training six times a year, which are pre-operational supervisor test, first operational management test, and intermediate operational supervisor test.

The operational supervisors were recommended by each sub/contractor to be submitted to the largest coal mining company in South Kalimantan on condition. After the debriefing was carried out, a competency test was conducted to select the firstlevel operational supervisor, and intermediate-level operational supervisor.

\section{General Morning Talk}

General Morning Talk (GMT) was conducted every first Wednesday at the beginning of the month. During the GMT activity, it was reported that various findings were made by the coal mining companies, including reporting accidents, reporting coal production, and awarding workshop appraisals. In the workshop appraisal, every month inspection was carried out in all existing workshops, henceforth, judgments were given based on the colour of the flag, starting from the lowest red, blue, to the best green for sub/contractor.

\section{Technology Guidance}

Technology guidance was carried out by coal mining companies, one of which was the management of waste cooking oil or food processing leftovers, to be recycled and turned into car fuel. Another program promoted was the solid waste recycling program to be managed by each sub/ contractor, so that it was in accordance with the principles of the $3 \mathrm{R}$, namely reuse, reduce, recycle.

\section{OSHE Seminar}

The seminars were conducted concerning awarness related to narcotics, psychotropic substances and forbidden substances, technical seminars especially regarding maintenance, because there were so many heavy equipment in the mining area, mining safety management system seminars, and health seminars. This OSHE seminar was held twice a year. The theme of each seminar varies according to the needs and conditions that exist.

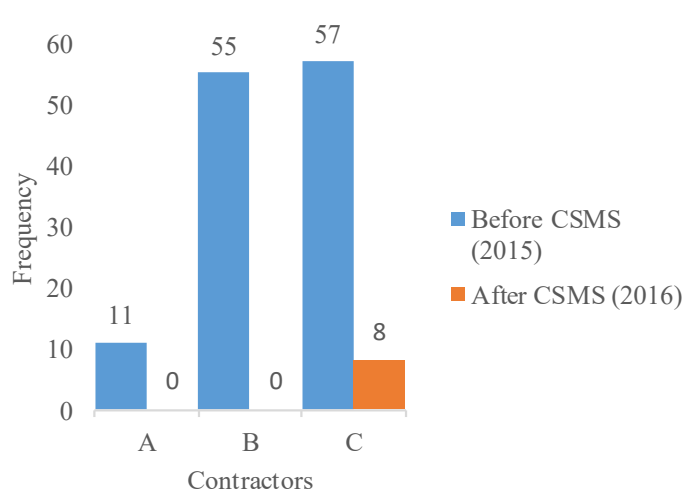

Figure 2. The Number of Work Accidents at Three Main Contractors Before and After the Implementation of CSMS in the Largest Coal Mining Company in South Kalimantan

\section{Audit}

The CSMS audit was conducted for the first time in 2014. Furthermore, in 2016, a CSMS audit was carried out, but using PERMEN ESDM reference No. 38 of 2014 concerning the application of the Mining Safety Management System (MSMS).

\section{The Impact of the Implementation of CSMS on Work Accident Rates in Coal Mining Company}

In general, the coal mining company had three main contractors, namely main contractor $\mathrm{A}$, main contractor $\mathrm{B}$, and main contractor $\mathrm{C}$. Before the implementation of audit and improvement of CSMS, there were a number of work accident cases at each main contractor.

In 2015, main contractor A had 11 work accidents, main contractor B had 55 work accidents, and main contractor $\mathrm{C}$ had 57 work accidents. However, after the implementation of CSMS in 2016, the number of work accident at those three main contractors decreased, as presented in Figure 2.

\section{DISCUSSION}

\section{The Implementation of CSMS}

\section{Risk Assessment Stage}

The risk assessment carried out at the largest coal mining company in South Kalimantan was carried out based on a description of activities in the production flow, where the hazards were identified based on the level of risk obtained from 
the likelihood of an incident and the severity of the incident, ie low, medium, or high risk.

Sub/contractors were required to attach a Hazard Identification and Risk Assessment (HIRA) and Job Safety Analysis (JSA) of each activity to be carried out, according to the type of sub/contractor.

The elements assessed in the risk assessment conducted by the largest coal mining company in South Kalimantan included routine activities, nonroutine activities, and activities of all personnel who have access to the workplace including guests. Meanwhile, according to other studies, the element of risk assessment consisted of people, labor and/or society, the environment, assets and reputation (Arif, Camelia and Purba, 2016).

Risk assessment was a basic and initial step in efforts to prevent work accidents through CSMS because in an occupational activity there was an unidentified risk which can lead to obstacles in operational activities, so risk assessment must be carried out comprehensively (Setianingrum and Susilowati, 2020).

\section{Pre-Qualification Stage}

First of all, the largest coal mining company in South Kalimantan held a discussion about the requirements that needed for sub/contractors in accordance with the type of work and the result of risk assessment. This is in line with another research project that states the requirements that made by user or company will be used as contractor's work guidelines (Suaery, Kurniawan and Ekawati, 2016).

The largest coal mining company in South Kalimantan selected the sub/ contractor directly. Pre-qualification was done by giving the contractor questionnaire and submitting administrative requirements along with supporting documents that must be attached. Then, the largest coal mining company in South Kalimantan would evaluate and verify the document by visiting the sub/contractor location to prove the implementation of occupational safety and health management system in the company.

The largest coal mining company in South Kalimantan set a minimum value of 27 points $(67.5 \%)$ out of a maximum total of 40 points for sub-contractors/ contractors regardless of the level of risk.

Whereas, based on previous research, mining companies in Balikpapan City set a minimum value standard based on the level of risk, where a value of 60 is given for low risk activities, 70 for medium risk, and 80 for high risk (Ananta, 2016).

Based on other studies, it was known that $72.6 \%$ of the quality of construction project work was affected by the qualifications of prospective contractors (Hasyim, 2016).

This is in line with other research in which, the better the OSH management system including the pre-qualification stage in CSMS, the better the performance of occupational safety and health and the competitiveness of a company will be (Margaretha, 2011).

This can occur because the purpose of the prequalification stage is to screen potential contractors and ensure that the selected contractor has the experience, resources and abilities needed to carry out work safely, environmentally friendly and sensitive to social impacts on the local community (Arif, Camelia and Purba (2016)), so that work accident cases do not occur and operational activities run well.

\section{Qualification/Selection Stage}

At this stage, the sub/contractor submited a CSMS submission by making a CSMS registration request letter and attaching the partner letter. Furthermore, the largest coal mining company in South Kalimantan provided a filling form as a condition to fulfill CSMS requirements which then was distributed to sub/contractors.

The requirement that must be fulfilled by sub/ contractor in the largest coal mining company in South Kalimantan were whether the sub/ contractor have mining service license, certificate of registration, regular health check, supervisor's competencies, equipments's licence, and an OSH management system.

Passing standard used for the sub/ contractor has met the requirements in aspects of Occupational Safety and Health and the Environment (OSHE). Sub-contractors who passed the data were verified and obtained a CSMS feasibility test after they were declared to meet CSMS requirements.

\section{Pre-Job Stage}

Coal mining companies hold meetings with $\mathrm{sub} /$ contractors to ensure that aspects relevant to the contract risk assessment and all other OSHE aspects in the contract are communicated and understood by all parties prior to contract implementation.

The purpose of this communication is to ensure that the wishes and expectations of the user can be 
understood by the sub/ contractor (Setianingrum and Susilowati, 2020).

At this stage, workers from the sub/ contractor who carried out their work in the largest coal mining company in South Kalimantan were given induction for new employees, while for old employees got reinduction.

According to UU No. $1 / 1970$, it is stated that new workers must obtain an explanation of the conditions and hazards that exist and that may arise in the work area (President of Republic of Indonesia, 1970).

\section{Monitoring}

The number of active subcontractors registered in February 2017 period at the largest coal mining company in South Kalimantan was 151 companies and the sub-contractor conducted a monthly selfassessment and the results were sent to the CSMS coal mining company staff to be included in the database for monitoring.

The inspection program was also conducted by the largest coal mining company in South Kalimantan's QHSE department was an inspection workshop which was held once a month. The purpose of this inspection is to determine the conditions and unsafe behaviour as early as possible so that prevention and control measures can be taken (Gyatri, 2011).

After the assessment, the sub/contractor obtained a ranking in the form of a flag based on the level of compliance. Sub/ contractors with a low level of compliance were given a red flag, a medium level of compliance was given a blue flag, and a high level of achievement was given a green flag.

In 2017, all existing sub/ contractors have achieved CSMS achievement points above $70 \%$ because all sub/ contractors have fulfilled the CSMS requirements so that one of the CSMS goals to ensure that the sub/ contractor has a safe management system has been achieved.

\section{Evaluation}

CSMS audit activities were first carried out by the CSMS Section Department QHSE System in 2014 and continued in 2016 using the Mining Safety Management System tools.

This is in line with Government Regulation of the Republic of Indonesia No. 50/2012 about the Implementation of the Occupational Safety and Health Management System which states that employers must carry out monitoring and evaluation of OHS performance (Goverment of Rebuplic of Indonesia, 2012).

Based on a study, the output from the evaluation can be used by the company (user) as a reward and punishment for sub/ contractors so that their contractor's work motivation can increase (Gyatri, 2011). This is in line with other studies, where the largest Indonesian oil company owned by the Indonesian government gives awards and sanctions to contractors based on the results of the evaluation of OSH performance during work implementation (Santoso et al., 2015).

\section{Improvement of OSHE Contractor Program}

\section{Supervisor Competency Training}

The largest coal mining company in South Kalimantan facilitates the contractor or subcontractor in carrying out the competency test of the OSHE supervisor, which is conducted six times a year. The operational competency activities undertaken by coal mining companies are the competencies of first operational supervisor and intermediate operational supervisor.

The supervisors are recommended by each sub/contractor to be submitted to the largest coal mining company in South Kalimantan with the minimum requirements to become a supervisor that has experience in working in a coal mining company for at least one year for the Bachelor, three years for diploma graduates, and ten years for high school graduates.

The competency test aims to supervise the competencies of the supervisors in accordance with their respective competencies, and be able to run their jobdesk properly. This is in line with other research project stating that weak competence of a person in charge and auditor can lead to an error that affects the company's operations (Anggoro and Simorangkir, 2019). Another study stated that supervisor competency training has a positive regression towards the quality of human resources, including the staffs (Handayati, 2012).

\section{General Morning Talk}

General Morning Talk was conducted twelve times a year, which was every Wednesday in the first week. This activity was attended by representatives of all sub/ contractors. In general, general morning talk is the same as safety talk, which discusses 
various activities carried out in coal mining companies, including discussing accident reporting, coal production reporting, and awarding that comes from the results of workshop evaluations, as a call for increased OSH implementation to the entire workforce.

Based on other study, it was known that K3 communication (safety talk) with $\mathrm{OSH}$ behavior has a strong relationship (Suyono and Nawawinetu (2013)), so that the general morning talk activities carried out by coal mining companies are appropriate because they were carried out routinely with varied material.

General morning talk activities carried out by mining companies were in accordance with Law No. 1/ 1970 regarding management is required to provide guidance for all workers under its leadership, in preventing accidents and combating fires, as well as improving work safety and health, also in providing first aid for accidents (President of Republic of Indonesia, 1970).

\section{Technology Guidance}

The largest coal mining company in South Kalimantan have policies related to the environment in the scope of contractors, which is by applying the principles of Reuse, Reduce, and Recycle (3R). All solid waste products from each company, both contractors and sub-contractors, are processed by way of implementing the $3 \mathrm{R}$ principle.

This is in accordance with Law No. 18/2008 on Waste Management which outlines the three main activities in the implementation of waste reduction activities, those are limitation of landfill waste, recycling of waste, and reuse of waste (President of Republic of Indonesia, 2008). The application of 3R in mining areas provides environmental, economic and social benefits. Based on a study, the application of $3 R$ in used oil waste in the mining area can reduce 3,585,233.33 liters of oil waste and provide a profit of Rp. 32,035,262,783 for four years of use (Widiyanto, 2016).

\section{OSHE Seminar}

The largest coal mining company in South Kalimantan regularly held OSHE seminars every year, precisely during the OSH month. This was done because based on the Kepmenaker 386/2014. it was mentioned that one of the activities of the OSH month activities are helding of a convention/ seminar/workshop.
Based on other study, the OSHE seminar is a OSH system that is usually directed at supervisors to improve their knowledge and skills in implementing the OSH programs at work (Gemely, 2018).

Another study stated that there was a significant regression between employee performance and OSH programs, such as seminar (Fajri, Utami and Prasetya, 2017).

\section{Audit}

CSMS audit was conducted by coal mining companies for the first time in 2014. This activity was carried out every year in June using the PERMEN ESDM reference No. 38/2014. This is in line with PERMEN ESDM No. 38 of 2014. Based on a study, audit activities are performed at least once a year (Veronica, 2018).

The MSMS audit aims to increase subcontractors in the implementation of the MSMS, because if the MSMS point increased, it can be ascertained that CSMS points increased. This is consistent with Ramli's statement that an audit is carried out on work processes to assess workforce performance (Silaban, 2009).

\section{The Impact of the Implementation of CSMS on Work Accident Rates in Coal Mining Company}

CSMS was effectively used to reduce and prevent the work accidents (Wachter and Yorio, 2014). Main contractor A provides infrastructure development services, mining construction, land clearing, drilling and blasting, overburden removal, coal mining and transportation, reclamation and rehabilitation of mine sites. Main contractor B provides coal mining and final coating services. Main contractor $\mathrm{C}$ provides coal mining operations in the run of mine area.

Before auditing and improving the implementation of CSMS, those main contractors had experienced work accidents. In 2015, there were 11 work accidents that occured at the main contractor A, including one work accident that needed first aid treatment, three work accidents that needed medical help but did not caused lost of workdays, and seven cases of property damages.

There were 55 work accidents that occured at the main contractor B in 2015, including six work accidents that required first aid treatment without losing workdays, two cases of work accidents that caused fractures, 46 cases of property damages, and 1 work accident that caused a permanent dissability. 
Cases of work accidents that occurred at the main contractor $\mathrm{C}$ in 2015 were 57 incidents, consisting of 6 minor work accidents that needed first aid treatment, 3 cases of work accidents that required medical treatment but did not loss working days, 47 cases of property damage, and an environment incidents.

However, after an audit and improvement of the implementation of CSMS, contractor A and contractor B won a zero accident award from the South Kalimantan Ministry of Labor, because the two contractors succeeded in carrying out the work safely without causing an adverse incident. Meanwhile, the main contractor $\mathrm{C}$ managed to reduce the accident rate by $86 \%$.

This is consistent with the results of other study which stated that companies that implement CSMS are able to prevent and control hazards that exist in the workplace so as to minimize the risk of workplace accidents (Sari, 2017). This statement is further strengthened by other research which stated that companies that implement a health and safety management system have a lower accident rate than companies that do not implement it (Yoon et al., 2013).

\section{CONCLUSION}

The largest coal mining company in South Kalimantan has been carrying out CSMS activities since 1990 but that it was not implemented effectively. In 2014, there was a data collection on the existing sub/contractors and determining of risk profiles. In 2015, CSMS started to integrated, optimized of the empowerment, and the periodic audits were conducted. CSMS activities were carried out, starting with conducting risk analysis, prequalification, qualification, pre-work, monitoring and evaluation. To streamline OSHE activities, coal mining companies conducted a number of businesses including operational competency competencies, general morning talk, technology guidance, OSHE seminars, and audits. Appropriate implementation of CSMS in coal mining company succeeded in reducing work accident rates at those three main contractors, even makes two main contractors won zero accident award.

\section{ACKNOWLEDGEMENT}

I am really grateful to all who have helped me in the process of making this journal. I would like to show my gratitude to all the the lecturers of Occupational Safety and Health Department in Public Health Faculty of Universitas Airlangga for sharing their pearls of wisdom during the course of this research.

\section{REFERENCES}

Abdul-Rashid, I., Bassioni, H. and Bawazeer, F. (2007) 'Factors Affecting Safety Performance in Large Construction Contractors in Egypt', Association of Researchers in Construction Management, ARCOM 2007 - Proceedings of the 23rd Annual Conference, 2(September), pp. 661-670.

Ananta, E. (2016) 'Peran Contractor Safety Management System dalam Meminimalkan Risiko Kecelakaan Kerja pada Proyek Pembangunan Waduk Teritip Kota Balikpapan', in Prosiding Program Pascasarjana Fakultas Kedokteran, Universitas Gadjah Mada. Yogyakarta: Gadjah Mada University Press, pp. 56-63.

Anggoro, Y. and Simorangkir, D. A. (2019) 'Analysis of Indonesia Mineral and Coal Mining Safety Management System Policy Using Soft System Methodology', Jurnal Manajemen Teknologi, 18(1), pp. 17-37.

Arif, M., Camelia, A. and Purba, I. G. (2016) 'Evaluasi Pelaksanaan Program Contractor Safety Management System (CSMS) pada Project Turnaround (TA) di PT. Pupuk Sriwidjaja (PUSRI) Palembang', Jurnal Ilmu Kesehatan Masyarakat, 7(1), pp. 14-21.

Bird, F. E., Germain, G. E. and Clark, M. D. (2003) Practical Loss Control Leadership. Third Edition. USA: Det Norske Veritas.

Fajri, K., Utami, H. and Prasetya, A. (2017) 'Pengaruh Program Keselamatan dan Kesehatan Kerja (K3) terhadap Kepuasan Kerja dan Kinerja Karyawan (Studi pada Karyawan PT Brantas Abipraya (Persero) dalam Proyek Pembangunan Wisma Atlet Kemayoran)', Jurnal Administrasi Bisnis S1 Universitas Brawijaya, 46(1), pp. 11-19.

Gemely, D. (2018) Implementasi Sistem Manajemen Keselamatan dan Kesehatan Kerja di PT. Pelindo IV (Persero) Terminal Petikemas Makassar Tahun 2018. Undergraduate Thesis. Makassar : Faculty of Public Health. Universitas Hasanuddin.

Goverment of Rebuplic of Indonesia (2012) Peraturan Pemerintah Republik Indonesia No. 50 Tahun 2012. 
Gyatri, M. J. (2011) Gambaran Pedoman Sistem Manajemen Keselamatan dan Kesehatan Kerja Kontraktor PT. MEDCO E\&P Indonesia serta Implementasi Sistem Manajemen Keselamatan dan Kesehatan Kerja Kontraktor Pada 18 Departemen User di Rimau Asset - PT MEDCO E\&P Indonesia Tahun 2011. Undergraduate Thesis. Depok : Faculty of Public Health. Universitas Indonesia.

Handayati, R. (2012) 'Analisis Kebutuhan Pelatihan Keselamatan dan Kesehatan Kerja (K3) bagi Karyawan Tingkat Supervisor', Jurnal EKBIS, VI(1), pp. 357-361.

Haryanti, T. (2016) Penerapan Contractor Safety Management System pada Contractor Clinic sebagai Upaya Pemenuhan Standar K3 di PT Coca Cola Amatil Indonesia Central Java. Undergraduate Thesis. Surakarta : Faculty of Medicine. Universitas Sebelas Maret.

Hasyim, S. (2016) 'Pengaruh Kualifikasi Kontraktor Terhadap Kualitas Pekerjaan Proyek Konstruksi di Kabupaten Halmahera Barat', Jurnal Ilmiah Media Engineering, 6(1), pp. 463-476.

Hermanus, M. A. (2007) 'Occupational Health and Safety in Mining — Status, New Developments , and Concerns', The Journal of The Southern African Institute of Mining and Metallurgy, 107(1), pp. 531-538.

International Labour Organizational (2013) Keselamatan dan Kesehatan Kerja Sarana untuk Produktivitas. Jakarta: International Labour Office.

Margaretha, F. (2011) 'Evaluasi Pengaruh Sistem Manajemen Keselamatan Kerja dan Kesehatan Terhadap PT X', Jurnal Riset Manajemen Sains Indonesia (JRMSI), 2(2), pp. 34-57.

Minister of Energy and Mineral Resources (2014) Peraturan Menteri Energi dan Sumber Daya Mineral Republik Indonesia No. 38 Tahun 2014 tentang Penerapan Sistem Manajemen Keselamatan Pertambangan Mineral dan Batubara. Jakarta: Ministry of Energy and Mineral Resources.

Pratiwi, H. Y. (2017) 'Analisis Penerapan Contractor Safety Management System (CSMS) Di PT. X, Bontang, Kalimantan Timur', The Indonesian Journal of Occupational Safety and Health, 6(2), pp. 187-196.

President of Republic of Indonesia (1970) UndangUndang Republik Indonesia No. 1 Tahun 1970 tentang Keselamatan dan Kesehatan Kerja. Jakarta: President of Republic of Indonesia.
President of Republic of Indonesia (2008) UndangUndang Republik Indonesia No. 18 Tahun 2008 tentang Pengelolaan Sampah. Jakarta: President of Republic of Indonesia.

Ramli, S. (2008) Contractor Safety Management System. Jakarta: PT. Dian Rakyat.

Santoso, K. D. et al. (2015) 'Analisis Implementasi Contractor Safety Management System ( CSMS ) Terhadap Pekerjaan Berisiko Tinggi di PT Pertamina ( Persero ) Refinery Unit IV Cilacap', Jurnal Kesehatan Masyarakat (e-Journal), 3(3), pp. 475-484.

Sari, T. O. (2017) 'Identifikasi Hazard pada Pekerja Kontraktor Sipil dengan Metode CSMS di PT. X Pasuruan', The Indonesian Journal of Occupational Safety and Health, 6(1), pp. 88-96.

Setianingrum, A. and Susilowati, I. H. (2020) 'Pro Health Jurnal Ilmiah Kesehatan Analisis Manajemen Risiko Keselamatan di Perusahaan Kontraktor Pertambangan Batubara Site XYZ Berdasarkan Sistem Manajemen Keselamatan Pertambangan Mineral dan Batubara', Pro Health Jurnal Ilmiah Kesehatan, 2(1), pp. 7-15.

Silaban, G. (2009) 'Hubungan Angka Kecelakaan Kerja dengan Tingkat Pemenuhan Penerapan Sistem Manajemen Keselamatan dan Kesehatan Kerja', Berita Kedokteran Masyarakat, 25(3), pp. 156-166.

Suaery, Z. A., Kurniawan, B. and Ekawati (2016) 'Analisis Implementasi Contractor Safety Management System (CSMS) pada Tahap Persiapan Kerja di Coca Cola Amatil Indonesia (CCAI) Semarang', Jurnal Kesehatan Masyarakat (e-Journal), 4(3), pp. 646-656.

Suyono, K. Z. and Nawawinetu, E. D. (2013) 'Hubungan Antara Faktor Pembentuk Budaya Keselamatan Kerja dengan Safety Behavior di PT Dok dan Perkapalan Surabaya Unit Hull Construction', The Indonesian Journal of Occupational Safety and Health, 2(1), pp. 67-74.

Veronica, M. B. (2018) Analisis Implementasi Contractor Safety Management System CSMS) pada Tahap Pelaksanan di PT . Petronesia. Undergraduate Thesis. Medan: Faculty of Public Health. Universitas Sumatera Utara.

Wachter, J. K. and Yorio, P. L. (2014) 'A System of Safety Management Practices and Worker Engagement for Reducing and Preventing Accidents: An Empirical and Theoretical 
Investigation', Indiana University of Pennsylvania, 68(1), pp. 117-130.

Widiyanto, D. (2016) 'Pemanfaatan Limbah Oli Bekas Sebagai Bahan Bakar Pembantu Peledakan (ANFO) pada Kegiatan Pertambangan Batubara (Kasus Pemanfaatan Limbah Oli Bekas di PT. JMB Group)', e-Repository BATAN, XIV(1), pp. $52-59$.
Yoon, S. J. et al. (2013) 'Effect of Occupational Health and Safety Management System on Work-Related Accident Rate and Differences of Occupational Health and Safety Management System Awareness Between Managers in South Korea's Construction Industry', Occupational Safety and Health Research Institute, 4(4), pp. 201-209. 